\title{
Effect of Different Packaging Material on Shelf Life and Quality of Banana (Musa spp)
}

\author{
Kifle Zerga Birhanu Tsegaye \\ Wolkite University, Ethiopia
}

\begin{abstract}
An experimental was carried out at Wolkite university horticulture laboratory to investigate the effect of different packaging materials on shelf life and quality of banana fruits. the experimental treatments were different packaging materials (banana leaf, straw, card board (carton) and polyethylene bag) and control. The experiment was laid out in a complete randomized design (CRD) with three replications. Data was collected from each packaging materials between the gap of 4 days interval, sample of banana fruits in each treatment was taken to measure color, TSS, physiological weight loss, $\mathrm{pH}$ and shelf life. The analysis of variance (ANOVA) for all the recorded parameters of weight loss, pH, Total soluble solid (TSS) and color were showed highly significantly $(\mathrm{p}<0.01)$ difference. The highest physiological weight loss $(21.74)$ was recorded at the control (unpackaged) followed by banana leaf (15.59) whereas the lowest weight loss (6.56) was recorded from polyethylene bag. Bananas fruits packed using polyethylene bag, teff straw and banana leaf developed excellent type of colour whereas fruits kept in carton and the control showed dull type of colour. The highest $\mathrm{pH}$ value was recorded for bananas packed by banana leaf and teff straw whereas the lowest $\mathrm{pH}$ was observed in the control treatment followed by banana treated by carton box and polyethylene bag. $\mathrm{pH}$ of the banana fruit increased with the advancement of fruit ripening. the maximum value of TSS was recorded on fruits treated by polyethylene bag $\left(21.36{ }^{0}\right.$ Brix $)$ followed by teff straw $\left(20.36^{\circ}\right.$ brix $)$ whereas the minimum value of TSS was recorded in the control (13.88 ${ }^{0}$ Brix).
\end{abstract}

Keywords: Banana, Packaging Materials, Shelf Life

DOI: $10.7176 / \mathrm{JAAS} / 61-01$

Publication date: February $29^{\text {th }} 2020$

\section{Introduction}

Banana (musa spp) is a member of Musacea family and native to south east Africa. It is the most popular fresh fruit all over the world and its name comes from the Arabic word 'banan', which means finger. Banana is a large perennial herb with leaf sheaths that form the trunk like pseudostem. They vary in height from 1.5-8 m (Hailu et al., 2014). Banana is a very popular fruit due to its low price and high nutritive value. It is consumed both in fresh and cooked form both as ripe and raw fruit. Banana is a rich source of carbohydrate and is rich in vitamins particularly B. It is also a good source of potassium, phosphorus, calcium and magnesium. The fruit is easy to digest, free from fat and cholesterol. It helps in reducing the risk of heart diseases when used regularly and is recommended for patients suffering from high blood pressure, and kidney disorders. Processed products, such as chips, banana puree, jam, jelly, juice, wine and halwa can be made from the fruit. Banana can be utilized for the production of edible vaccine against Hepatitis- B virus (HBV). The plant based vaccine for HBV from edible banana seems to be an economical alternative for human healthcare by many scholars. The total area under banana in the world is 11.13 million ha, producing 97.38 million tons of banana and plantains. India is the largest producer of banana in the world, contributing $24 \%$ to the global production with a total area of 0.565 million ha and production 19.1 million tons reported for the year 2011 (FAO, 2011).

Ethiopia lies in the tropics where vast areas are suitable for banana growing. Banana production in Ethiopia ranges from homestead to large commercial plantations. At present, bananas are the leading fruit crops produced in the country both in terms of area coverage (28,695 ha) and production (1,245,615.60 qt year $\left.{ }^{-1}\right)(\mathrm{CSA}, 2004)$. Banana production in Ethiopia ranges from homestead to large commercial plantations. Banana research focused on varietal development, selecting of disease resistant variety, fertilizer trial, clump management practices and irrigation trials. Even though these pre-harvest practices are compulsory they must be coupled with the postharvest management practices because postharvest losses are of major concerns in many developing countries (Workneh et al., 2011a, 2011b).

There is a potential for export, being located close to important markets, such as Saudi Arabia, Djibouti and Somalia. Despite these facts, marketing of fresh bananas is complicated by postharvest losses. Both the fresh market and processing plants for fruits are located in towns away from farms and producers in rural areas. The quality of the fresh and processed fruit depends on the postharvest handling during harvesting, transportation, and storage, and should be monitored effectively to keep the best quality of fruit at harvest. Lack of storage facilities, limited access to transportation, and risk of high losses, growers are often forced to dispose off their produce over a short period of time (Haidar and Demisse, 2012). which causes an economic loss of banana. Although, the country is experiencing huge postharvest losses of banana, very little or no emphasis is given to 
postharvest handling of perishable produces. In most of the time the traditional packaging method for banana is best packaging in which dried banana leaf and straw of teff are used but the effectiveness of these packaging materials even has not yet been investigated. Modified atmospheric packaging (MAP) has also been found to increase the shelf life of banana fruit. It is often desirable to generate an atmosphere low in $\mathrm{O}_{2}$ and/or high in $\mathrm{CO}_{2}$ to influence the metabolism of banana being packaged or the activity of decay-causing organisms to increase storability and/or shelf life. In addition to atmosphere modification, MAP vastly improves moisture retention. Furthermore, packaging isolates the product from the external environment and helps to ensure conditions (Beaudry, 2000).

The quality of banana is reduced and considerable amount is wasted, from harvesting to final consumption. This loss can be kept at minimum by improving postharvest handling techniques through the use of packaging materials or through improving traditional packaging practices. Therefore, this study was aimed at the shelf life extension of banana using an appropriate packaging material. Despite these facts, marketing of fresh produce including bananas is complicated by postharvest losses both in terms of quantity and quality between harvest and consumption. Both the fresh market and processing plants for fruits are located in towns away from farms and producers in rural areas. The quality of the fresh and processed fruit depends on the postharvest handling during harvesting, transportation, and storage, and should be monitored effectively to keep the best quality of fruit at harvest. Because of a rain-fed farming system, lack of storage facilities, limited access to transportation, and risk of high losses, growers in Ethiopia are often forced to dispose off their produce over a short period of time which causes an economic loss of horticultural crops in general and fruits in particular (Haidar and Demisse 2007; Tigist et al., 2011). Generally, significant proportion of banana fruits have been lost in Ethiopia as well as in gurage zone due to lack of awareness on effect of packaging materials on shelf life and quality of harvetsed banana fruit. Hence, it is necessary to assess the effect of different packaging using different local materials on quality and shelf life of banana.

\subsection{Objectives}

\subsubsection{General objective}

$>$ To evaluate the effect of different packaging materials on shelf life and quality of banana fruit

\subsubsection{Specific objective}

$>$ To identify the best packaging material for incraesed shelf life and quality of banana

\section{Materials and Methods}

\subsection{Description of the study area}

The experimental study was carried out at Wolkite university, Horticulture laboratory to evaluate the effect of different packaging materials on shelf life and quality of banana fruits. The experimental laboratory is located in south west of Ethiopia about $170 \mathrm{~km}$ far from Addis Ababa. It also located about $7.8^{\circ}-8.5^{\circ} \mathrm{N}$ latitude and $37.5^{\circ}$ $38.7^{\circ} \mathrm{E}$ longitude. Wolkite comprises an altitude of 1300 meters above sea level (m.a.s.l). The mean annual temperature ranges from 14 to $24^{\circ} \mathrm{c}$ with an average of $20.5^{\circ} \mathrm{c}$. The soil type of the area heavy vertisol around $80 \%$ which is reach in organic matter while less capability to drain water. The rainfall of Wolkite is bimodal in which $80 \%$ rain fall in summer period of June to August whereas $20 \%$ in the belg period of February to May (GZADD, 2011).

\subsection{Experimental Materials}

Different materials were used for this experiment. Harvested green, physiologically matured banana fruits of "habesha" cultivar was used as experimental material. In addition to this, different packaging materials (teff straw, banana leaf, card board (carton), polyethylene), meter, sensitive balance, refractometer and $\mathrm{pH}$ meter were used also for measuring data.

\subsection{Treatments and Experimental Design}

The treatments were consisted of five different banana fruit packaging materials (teff straw, banana leaf, card board (carton), plastic polyethylene bag) and control treatment. The experiment was laidout in a complete randomized design (CRD) with three replications.

\subsection{Experimental Procedure}

The experiment was investigated in laboratory condition. Physiologically green mature habesha banana fruit were harvested from wabe research site. Transportation was done during morning and fruits were covered with news paper to avoid light and heat damage. Uniform fruits were washed with tap water to remove field heat, to reduce microbial population and to get rid of soil particles on the surface of fruits. In laboratory the collected banana was divided into 15 observations. 15 matured banana fruits were packed within each packaging materials and stored in laboratory at room temprature. The samples had uniform size, shape and color. The graded fruits 
were packed using each packaging materials and placed or arranged in the storage room with three replication. Five fruits were packed per treatment and twenty five fruits per replication. A total of 75 fruits were used for all the five packaging materials and three replications.

\subsection{Data Collection}

Data were collected from banana fruit of different packaging materials on four days interval. The sample of banana fruits in each treatment was taken randomly for assessment. Data was recorded at four days' interval over the storage period.

\subsubsection{Physical Parameters}

Physiological weight loss (TWL): The initial weight of banana fruits were taken before storing at different packaging materials and records the weight at four days interval. The sum of the weight loss were taken as the four days interval gives total weight loss, which was converted to percentage weight loss using the following formula.

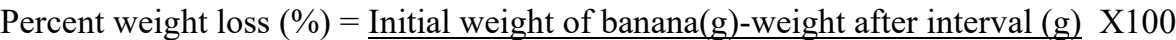

$$
\text { Initial weight of banana }(\mathrm{g})
$$

Colour: Colour was measured by comparing with the colour chart described by Dadzie and Orchard (1997). The chart consisted of the seven stage of banana ripening where 1 is dark green, 2 is light green, 3 is more green than yellow, 4 is more yellow than green, 5 is yellow with green tips, 6 is fully yellow, and 7 is flecking (Kader 1992).

\subsubsection{Chemical Parameters}

\section{Total soluble solids $\left({ }^{\circ}\right.$ Brix)}

Sample fruits were blended using a juice blender and TSS of the juice was measured by the refractive index, expressed as ${ }^{\circ}$ Brix, using a bench top digital Refractometer (Model: SN-003007).

Pulp pH

The $\mathrm{pH}$ of the sample fruit juice was measured using a bench top digital $\mathrm{pH}$ meter (model: CP-505, Poland). The $\mathrm{pH}$ meter was periodically calibrated with buffer at $\mathrm{pH} 4.0$ and 7.0 before taking the measurements.

\subsubsection{Shelf Life}

The shelf life of the banana fruits was estimated as the number of days taken to reach the final ripe stage) of the fruit just before it enters the senescence (unmarketable) stage.

\subsection{Data Analysis}

All data were subjected to analysis of variance (ANOVA) by using statistix 8 software. All means were computed by using Tukey test at 5\% level of significance.

\section{Results and Discussion}

\section{Analysis of variance}

The analysis of variance (ANOVA) for all the recorded parameters of weight loss, $\mathrm{pH}$, Total soluble solid (TSS) and color were showed highly significantly $(\mathrm{p}<0.01)$ difference by different packaging materials.

\subsection{Physiological Weight Loss}

From the current study weight loss of banana fruit was significantly affected by packaging material. Table 1 showed that there was a significant variation in physiological weight loss between the different treatments in the overall storage period. The highest physiological weight loss (21.74) was recorded at the control (unpackaged) followed by banana leaf (15.59) whereas the lowest weight loss (6.56) was recorded from polyethylene bag. Weight loss of fresh fruits is primarily due to transpiration and respiration (Tadesse, 2011). This is indirectly influenced by packaging material. in polyethylene bag there is high relative humidity, low respiration rate and low concentration of temperature, so it reduce the weight loss of banana fruit (Blakely, 2011). Low temperature storage reduces the rate of respiration and ethylene production resulting in retarded physiological weight loss and an extended shelf life (Hoffman et al., 2002a; Perez et al., 2004; Workneh and Osthoff, 2010; Get net et al., 2011). Generally, fruits kept in plastic films had the lowest weight loss than banana fruits kept in the other packaging materials and the control. The loss associated with control fruits during the storage period under ambient condition. This result agreed with Thompson (2001) who reported that weight loss of fruits in polyethylene bags was far low than from unpackaged fruits.

\subsection{Peel Color}

Packaging material had highly significant $(\mathrm{P} \leq 0.01)$ effect on the change in peel colour of banana fruits during the storage period (Table 1). Bananas fruits packed using polyethylene bag, teff straw and banana leaf developed excellent type of colour whereas fruits kept in carton and the control showed dull type of colour. Dadzie and Orchard (2007) reported that the market quality and consumer acceptance of banana are significantly influenced by the colour of the fruit. Thus, attractive yellow colour could be obtained by packaging of banana fruits in 
plastic bags, the most effective and acceptable packaging material when compared to others. This result is in line with Dadzie and Orchard (2007) who showed that attractive yellow colour could be obtained by packaging banana fruits in plastic bags, the most effective and acceptable packaging matetial when compared to others.

Table 1. Mean comparison for weight loss and color of banana fruit as influenced by packaging material

\begin{tabular}{|c|c|c|c|c|c|c|c|c|c|}
\hline \multirow[t]{2}{*}{ Treatments } & \multicolumn{4}{|c|}{ Weight Loss (g) } & \multirow{2}{*}{$\begin{array}{l}\text { Over all } \\
\text { mean }\end{array}$} & \multicolumn{3}{|c|}{ Color } & \multirow{2}{*}{$\begin{array}{l}\text { Over all } \\
\text { mean }\end{array}$} \\
\hline & Day 4 & Day 8 & Day 12 & Day 16 & & Day 8 & Day 12 & Day 16 & \\
\hline Polyethylene bag & 0.52 & 3.13 & 8.26 & 14.18 & $6.56^{\mathrm{d}}$ & 5.42 & 6.11 & 6.98 & $6.17^{\mathrm{a}}$ \\
\hline Carton box & 1.82 & 5.74 & 11.18 & 27.75 & $11.55^{\mathrm{c}}$ & 3.1 & 4.95 & 6.87 & $4.98^{b}$ \\
\hline Banana leaf & 3.10 & 7.06 & 14.13 & 38.08 & $15.59^{\mathrm{b}}$ & 4.95 & 5.09 & 5.87 & $5.09^{b}$ \\
\hline Teff straw & 2.32 & 6.59 & 14.12 & 33.42 & $14.11^{\mathrm{bc}}$ & 4.93 & 6.01 & 4.70 & $5.21^{\mathrm{a}}$ \\
\hline Control & 6.19 & 12.94 & 17.92 & 50.72 & $21.74^{\mathrm{a}}$ & 4.05 & 4.83 & 5.84 & $4.94 \mathrm{c}$ \\
\hline LSD & & & & & 3.12 & & & & 2.75 \\
\hline CV (\%) & 6.78 & 9.87 & 5.89 & 10.76 & 9.85 & 5.6 & 11.2 & 6.88 & 5.79 \\
\hline
\end{tabular}

\section{3. pH}

Changes in $\mathrm{pH}$ of the fruits treated at different packaging material are shown in Table 2 . The highest $\mathrm{pH}$ value was recorded for bananas packed by banana leaf and teff straw whereas the lowest $\mathrm{pH}$ was observed in the control treatment followed by banana treated by carton box and polyethylene bag. In general, $\mathrm{pH}$ of the banana fruit increased with the advancement of fruit ripening. Since acidity of the fruits is due to various organic acids that are consumed during respiration (Albertini et al., 2006). The acidity thus decreased with advancing maturity or increasing storage duration with a corresponding increase in fruit $\mathrm{pH}$ (Moneruzzaman et al., 2009). Amino acid has also been showed to be the main acid in banana juice, with $\mathrm{pH}$ of fruit normally between 6.2 and 6.7 (Babitha and Kiranmayi, 2010).

\subsection{Total soluble solid ( $\left.{ }^{0} \mathrm{brix}\right)$}

Statistically significant variation was observed among treatments on total soluble solids (TSS). Thus, the maximum value of TSS was recorded on fruits treated by polyethylene bag $\left(21.36{ }^{0}\right.$ Brix $)$ followed by teff straw $\left(20.36^{\circ}\right.$ brix) whearas the minimum value of TSS was recorded in the control (13.88 $\left.{ }^{0} \mathrm{Brix}\right)$. Increase of TSS content was observed in the present investigation agrees with the report by Abdullah et al. (2916) and Sarket et al, (2005) which confirms TSS of fruits increase along the storage time. The increased TSS value might be due to the physiological aspects of banana fruits, suppressed respiration and metabolic processes, which involved increasing TSS at different magnitudes (Awoke et al., 2012).

Table 2. Mean comparison for $\mathrm{pH}$ and total soluble solid of banana fruit as inlfuenced by packaging material

\begin{tabular}{|c|c|c|c|c|c|c|c|c|}
\hline \multirow[t]{2}{*}{ Treatments } & \multicolumn{3}{|c|}{ pH } & \multirow{2}{*}{$\begin{array}{l}\text { Over all } \\
\text { mean }\end{array}$} & \multicolumn{3}{|c|}{ TSS } & \multirow{2}{*}{$\begin{array}{l}\text { Over all } \\
\text { mean }\end{array}$} \\
\hline & Day 8 & Day 12 & Day 16 & & Day 8 & Day 12 & Day 16 & \\
\hline Polyethylene bag & 4.167 & 5.096 & 4.47 & $4.65^{\mathrm{ab}}$ & 20.41 & 22.41 & 21.27 & $21.36^{\mathrm{a}}$ \\
\hline Carton box & 4.40 & 5.123 & 4.18 & $4.56^{\mathrm{ab}}$ & 17.17 & 18.40 & 16.98 & $17.52^{\mathrm{bc}}$ \\
\hline Banana leaf & 4.883 & 5.81 & 4.753 & $5.15^{\mathrm{a}}$ & 4.48 & 17.27 & 15.96 & $15.91^{\mathrm{cd}}$ \\
\hline Teff straw & 4.567 & 4.986 & 4.50 & $4.70^{\mathrm{a}}$ & 9.31 & 21.53 & 20.23 & $20.36^{\mathrm{ab}}$ \\
\hline Control & 4.18 & 4.213 & 3.856 & $4.07^{b}$ & 5.35 & 14.15 & 11.47 & $13.88^{\mathrm{d}}$ \\
\hline LSD & & & & 5.76 & & & & 16.3 \\
\hline CV (\%) & & & & 5.99 & & & & 7.44 \\
\hline
\end{tabular}

\subsection{Shelf Life}

Shelf life is the period from harvesting up to the last edible stage (Sewed et al., 2006). The shelf life of a product depends on initial quality of the food products, amount of quality change that can be allowed, prevailing environmental condition, and brakes properties ofthe packaging materials, and compatibility between food product and packaging (Esa et al., 2015). Significant variation was obtained among the treatment combination in relation to shelf life extension of bananas. The banana fruit treated by poly ethylne bag showed the longest shelf life then followed by carton. The lowest shelf life had been recorded on non packaging (control). Similar results were also obtained by the effects of different postharvest treatments used in the investigation were significant in respect of prolonging the shelf life of banana. Control banana fruits showed the lowest shelf life as compared to those treated.

\section{Conclusion}

The quality of the fresh and processed fruit depends on the postharvest handling during harvesting, transportation, and storage, and should be monitored effectively to keep the best quality of fruit at harvest. Significant proportion of banana fruits have been lost in Ethiopia as well as in gurage zone due to lack of 
awareness on effect of packaging materials on shelf life and quality of harvetsed banana fruit. Hence, it is necessary to assess the effect of different packaging using different local materials on quality and shelf life of banana. Therefore, the current study is conducted with the objectives of to evaluate the effect of different packaging materials on shelf life and quality of banana fruit and identify the best packaging material. The experimental study was carried out at Wolkite University, Horticulture laboratory to evaluate the effect of different packaging materials on shelf life and quality of banana fruits.

The analysis of variance (ANOVA) for all the recorded parameters of weight loss, $\mathrm{pH}$, Total soluble solid (TSS) and color were showed highly significantly $(\mathrm{p}<0.01)$ difference by packaging materials. The highest physiological weight loss (21.74) was recorded at the control (unpackaged) followed by banana leaf (15.59) whereas the lowest weight loss (6.56) was recorded from polyethylene bag. Bananas fruits packed using polyethylene bag, teff straw and banana leaf developed excellent type of colour whereas fruits kept in carton and the control showed dull type of colour. The highest $\mathrm{pH}$ value was recorded for bananas packed by banana leaf and teff straw whereas the lowest $\mathrm{pH}$ was observed in the control treatment followed by banana treated by carton box and polyethylene bag. $\mathrm{pH}$ of the banana fruit increased with the advancement of fruit ripening. the maximum value of TSS was recorded on fruits treated by polyethylene bag $\left(21.36{ }^{0} \mathrm{Brix}\right)$ followed by teff straw $(20.36$ ${ }^{0}$ brix) whereas the minimum value of TSS was recorded in the control $\left(13.88^{\circ} \mathrm{Brix}\right)$.

Generally, we can conclude that polyethylene bag can provide increased shelf life and maintain good quality of banana fruit after harvesting. Therefore, using polyethylene bag is important for growers (farmers), wholesalers, retailers and consumers for maintaining banana quality and longer fruit shelf life.

\section{Recommendation}

Banana is highly perishable fruit. There are different factors that affect the shelf life of banana, like environmental condition (climacteric condition and temperature). Doing only on the effect of packaging material shelf life may not be sufficient, since it is also affected by other factors. therefore, from this single experiment it is impossible to give a conclusive recommendation. Therefore, further research investigation should be made by including advanced packaging materials with treating gents in different times to come up with conclusive recommendation.

\section{References}

Abdullah, H., M. A. Rohaya and H. Z. Zaipun. (2016). Physico- chemical changes during maturation and after ripening of bananas (Musa sapientum cv Embum ). MARDI Research Buletin, 13(3): 341-347.

Albertini, M.V., E. Carcouet, O. Pailly, C. Gambotti, F. Luro, and L. Berti, Changes in organic acids and sugars during early stages of development of acidic and acidless citrus fruit, J. of Agri. and Food Chem., 2006, 54, 8335-8339.

Awoke Zeweter, k.Woldestadik and T.S. Workineh.(2012). Effect of post-harvest treatmentson color and firmness changes of banana fruits during storage condition.

Babitha B, Kiranmayi p. (2010). Effect of storage conditions on the post-harvest quality of fruits .J. Res. Agri. Sci. 1(4): 409-411

Beaudry RM. Responses of horticultural commodities to low oxygen: limits to the expanded use of modified atmosphere packaging. HortTechnology. 2000;10:491-500.

Blakely P.J., Stubbing's B.A., Adkins M.F., Corcoran R.J., White A., and Woolf A.B., 2011. Low temperature conditioning before cold disinfestations improves 'Hass' banana fruit quality. post. Biol. Technol. 28(1):123-133.

Dadze P.J., Stubbing's B.A., Orchrd M.F., Marburg G.F., and Woolf A.B., 1997. Hot water treatments improve 'Hass' babana fruit quality after cold disinfestations. post. Biol. Technol. 24(2):183-192.

Easaya, I.L., 2015 Effects of clip vs. snap harvest of bananas on ripening and weight loss. J. Am. Soc. Horticulture. Sci. 98(1):106-108.

Famurawall P., Ekman J.S., Blumenthal C., Glasson B., Conroy J., and Helford P., 2013. The effects of short heat-treatments on the induction of chilling injury in banaba fruit (Persia Americana Mill). Post. Biol. Technol. 8(2):129-141..

FAOSTAT, 2011.Preliminary Data for Selected Countries and Products http://faostat.fao.org/site/567/DesktopDefault.aspx?PageID=5 Food and agriculture organization (FAO).United Nations. The state of food security in the world: addressing food insecurity in protracted crisis.

Garlic P., 2011 Reduction in monocarp discoloration in 'Fuertes' was achieved with 2\% oxygen and 10\% carbon dioxide at $5.5^{\circ} \mathrm{C}$ for 28 days.

Getnet H., Workneh T.S., and Woldetsadik K., 2011. Effect of maturity stages, variety and storage environment on sugar content of tomato stored in multiple pads evaporative cooler. Afr. J. Bioethanol. 10(80):1848118492. 
GZADD (Gurage Zone Agricultural Development Department), 2011. Documented report on socio-economic study of the zone.

Haidar and Demisse, and J., 2012. Percentage of dry matter and oil content are not reliable indicators of fruit maturity or quality in late-harvested 'Hass' banana . Hort science 35(4):694-695.

Hailu B.,2014. Postharvest application of 1-MCP to improve the quality of various banana cultivars.Post. Biol. Technol. 37(3):252-264.

Hailu Seyeum, Workineh; Belew D. (2012). Effect of packaging material on shelf lifeand quality of banana. Journal of food science and TechnologyVol 51(1 Pp47-63).

Kadar AA. 1992. Pre-harvest and postharvest factors influencing vitamin C contents ofChemistry60 (3), 331-3

Key V., Saggy S.I., and Pepsis E.,1995. Postharvest application of 1-MCP to improve the quality of various banana cultivars.Post. Biol. Technol. 37(3):252-264.

Lee P.J., Stubbing's B.A., Adkins M.F., Corcoran R.J., White A., and Woolf A.B., 2013. Low temperature conditioning before cold disinfestations improves 'Hass' banana fruit quality. post. Biol. Technol. 28(1):123-133.

Liu-Garcia J.A., Doyon G., Salazar-Garcia S., Goenaga R., and Gonzalz- Duran I. J.L2001b. Effect of harvest date and ripening degree on quality and shelf life of Hass banana in Mexico. Fruits 65(6):367-375.

Liu,L.J., Koo,N., and Min,D.,2002.Reactive oxygen species, aging, and antioxidativenutraceuticals. Comprehensive Reviews in Food Science and Food Safety, 3, 21-33.

Moneruzzaman, K.M., A.B.M.S. Hossain, W. Sani, M. Saifuddin, M. Alinazi (2009) Effect of harvesting and storage conditions on the postharvest quality of tomato (Lycopersicon esculentum Mill) cv. Roma VF Australian J. Cro Sci. Southern Cross J. 3: 113-121.

Sarker et.al, 2005. Handbook of Fruit Science and Technology. Marcel Dekker Inc., New York, p. 387.

Sewed A.,Muhammed A.,zia . Ahamed E. and Thompson, A.F. 2006. Improvement of banana quality in relation to storage humidity institute of Horticulture science.

Soliva Fortuny, S.(2004). Packaging and transportation of fruits and vegetables for better marketing.

Taddes F. 2011. Post harvest loss of fruits and vegetables in horticultural state farms. Acta Hortic 270:261-270.

ThopsonF., (2001). Post harvest loss of fruits and vegetables in horticultural state farms. Acta Hortic 270:261270

Villa-Rodriguez J.A., Molina-Corral F.J., Ayala-Zavala J.F., Olivas G.I., and González-Aguilar, G.A., 2001. Effect of maturity stage on the content of fatty acids and antioxidant activity 'Hass' banana. Food Res. Int. 44(5):1231-1237.

Workneh T.S., Osthoff G., and Steyn, M.S., 2011. Influence of preharvest and postharvest Ahmad S, Perviez MA, Thompson AK, Ullah H. Effects of storage of banana in controlled atmosphere before ethylene treatments on its ripening and quality. J Agric Res. 2006;44(3):219-22.

\section{Appendixes}

Appendix 1. Analysis of variance (ANOVA) for weight loss

\begin{tabular}{|l|l|l|l|l|l|}
\hline Source of variation & DF & SS & MS & F & P \\
\hline Treatment & 4 & 370.21 & 92.55 & $49.1^{* *}$ & 0.0000 \\
\hline Error & 10 & 18.84 & 1.88 & & \\
\hline Total & 14 & 389.05 & & & \\
\hline
\end{tabular}

Appendix 2. Analysis of variance (ANOVA) for $\mathrm{pH}$

\begin{tabular}{|l|l|l|l|l|l|}
\hline Source of variation & DF & SS & MS & F & P \\
\hline Treatment & 4 & 1.77 & 0.44 & $5.76^{*}$ & 0.0114 \\
\hline Error & 10 & 0.77 & 0.077 & & \\
\hline Total & 14 & 2.54 & & & \\
\hline
\end{tabular}

Appendix 3. Analysis of variance (ANOVA) for TSS

\begin{tabular}{|l|l|l|l|l|l|}
\hline Source of variation & DF & SS & MS & F & P \\
\hline Treatment & 4 & 114.79 & 28.7 & $16.3^{* *}$ & 0.0002 \\
\hline Error & 10 & 17.57 & 1.75 & & \\
\hline Total & 14 & 132.36 & & & \\
\hline
\end{tabular}

Appendix 4. Analysis of variance (ANOVA) for Color

\begin{tabular}{|l|l|l|l|l|l|}
\hline Source of variation & DF & SS & MS & F & P \\
\hline Treatment & 4 & 3.25 & 0.81 & $9.00^{* *}$ & 0.0023 \\
\hline Error & 10 & 0.9 & 0.09 & & \\
\hline Total & 14 & 4.03 & & & \\
\hline
\end{tabular}

